\title{
THE IMPORTANCE OF PROTECTED AREAS IN THE COUNTRIES OF THE EUROPEAN UNION
}

\author{
Joanna Stefanczyk ${ }^{1}$, MSc; Le Hoang Long ${ }^{2}$, MSc \\ ${ }^{1}$ Department of Economics and Organisation of Enterprises, Warsaw University of Life Sciences (SGGW), \\ ${ }^{2}$ International Economics Faculty, Banking University of Ho Chi Minh City
}

\begin{abstract}
The study describes the quantities of European Union Natura 2000 protected areas. The aim of research was to analysed Land areas of EU Member States covered by Natura 2000.The size of Site of Community Importance (SCI) and Special Protection Area (SPA) areas were compared among the countries of the European Union. Furthermore, the environmental protection transfers by environmental protection activity and institutional sector for years 2010-2015 were presented and their significant irregularity was featured. The analysis uses secondary data available on the European institutions websites. The result of the analysis was the observation of significant differences in the size of protected areas in different countries, where in some cases even $1 / 3$ of the country's territory is protected areas.
\end{abstract}

Key words: protected areas, Natura 2000, ecological farming, European Union. JEL code: Q50, Q56, Q57.

\section{Introduction}

Europe is a continent rich in valuable natural areas, which imposes on people the duty of their care, protection and keep for future generations. As much as $1 / 6$ of the land territory of the European Union is covered by the European Ecological Network Natura 2000 (Perepeczko B., 2012). Previous traditional forms of nature protection based on prohibitions and restrictions were not a sufficient solution for the habitats used for agriculture (Brodzinska K., 2013). Golebiewska and Pajewski emphasize that environmental issues once moved aside now in the aspect of agricultural activity are becoming more and more important (2015). Preventing the progressive degradation of the environment and restoring its damaged components require its users to use various ways of protection (Wielewska I., 2017). Therefore, if economy and the environment are to grow in harmony, two principles must be respected: 1) it is necessary to use renewable resources in a manner that warrants that the level of consumption of these is not higher than the level of production, 2) pollutants must not be generated in quantities that exceed the assimilative capacity of the environment (Golebiewska B., 2015; Wos A., Zegar J., 2002). The implemented network of Natura 2000 areas consists of special areas of habitat protection, special bird protection areas and areas of importance for the EU (Mickiewicz B., Gotkiewicz W., 2010). The development of the idea of nature conservation has progressed in individual countries at a varied pace. The process of European integration has facilitated the undertaking and coordination of activities for the coherent protection of natural heritage on the scale of almost the entire continent. The main issue in the aspect of the efforts of various European countries to protect nature has become the creation of a common legal basis. One of the first acts of this kind was the Ramsar Convention on the Protection of Wetlands (1971), the Bonn Convention on the Conservation of Migratory Species of Wild Animals (1979) and the Berne Convention on the Protection of Species of Wild European Fauna and Fauna and Natural Habitats (1982). These activities turned out to be insufficient, a symptom of which was the decline in biodiversity, still observed on a European and global scale. As a result, as part of the United Nations Conference on Environment and Development held in 1992 in Rio de Janeiro, further documents were adopted defining the fundamental principles in socio-economic policy requiring environmental protection, including the Convention on the Preservation of Biological Diversity (called the Rio Convention). The main goal of its implementation is to protect biodiversity on a global scale and sustainable use of environmental resources, as well as a fair distribution of 
benefits derived from genetic resources (General Directorate for Environmental Protection, 2014). In order to achieve such goals within the European communities, the so-called Bird Directive (Council Directive 79/409 / EEC of 2 April 1979 on the protection of wild birds, replaced by a new Directive 2009/147 / EC of the European Parliament and of the Council of 30 November 2009 on the conservation of wild birds). As an act of law closely related and developing a vision of the actions outlined earlier in relation to birds, in 1992 the so-called the Habitats Directive (Council Directive 92/43 / EEC of 21 May 1992 on the conservation of natural habitats and wild fauna and flora), which obliged the Member States of the European Union to introduce a legal basis for the development of a network of areas protecting endangered species on a European scale, animals and types of natural habitats. These two directives provide for the creation of a system of areas constituting a functionally coherent network - the European Ecological Network Natura 2000, enabling the implementation of a coherent nature conservation policy on the territory of the European Union, created by the Birds and Habitats designated areas of special bird protection (SPAs) and special areas habitat protection (SAC). The obligation to designate Natura 2000 sites applies to all EU Member States (General Directorate for Environmental Protection, 2014). The network in question is an open system, which means that the list of areas can be supplemented on a regular basis (Kamieniecka J., Wojcik B., 2010). Protection of these areas does not exclude their economic use, however, each project must be assessed. This concept is an attempt to reconcile the need for economic development with the need to protect the environment (Zapolska K., 2012). It is also an attempt to increase the social acceptance of activities related to nature conservation, understanding this problem and teaching people care for the environment in which they live. In 2009 Golebiewska revealed that the increase of relations with the environment positively affected the obtained efficiency. In addition, in the case of the need to limit economic activity in areas covered by Natura 2000, compensation was proposed (Jack B., 2009; Szramka M., Zebek E., 2013).

The experience of European Union countries shows that protected areas can provide tangible benefits to the local community, including material ones (Kielsznia M., 2010). Protected areas are usually located where there is high forest cover, poor soils, low population and insufficiently developed communication infrastructure and entrepreneurship (Zapolska K., 2012). An opportunity for the development of entrepreneurship is, for example, the creation of accommodation for tourists within their own farms or the running of an organic farm (Bera M., 2014). Organic farming is conditioned by various aspects, examples of which are presented in Table 1.

Table 1

Conditions that create the possibility of developing organic production

\begin{tabular}{|c|c|c|c|c|c|}
\hline & Financial & Environmental & Market & Social & Regional \\
\hline $\begin{array}{l}\text { create the } \\
\text { possibility of } \\
\text { developing } \\
\text { organic } \\
\text { production }\end{array}$ & $\begin{array}{l}\text { The } \\
\text { possibility of } \\
\text { financial } \\
\text { support, } \\
\text { subsidies }\end{array}$ & $\begin{array}{l}\text { Biodiversity, soil } \\
\text { fertility }\end{array}$ & $\begin{array}{l}\text { Resulting from the } \\
\text { prices of organic } \\
\text { products against } \\
\text { the background of } \\
\text { conventional } \\
\text { production }\end{array}$ & Lifestyle change & $\begin{array}{l}\text { Resulting from } \\
\text { the agrarian } \\
\text { structure and } \\
\text { the character } \\
\text { of the region }\end{array}$ \\
\hline
\end{tabular}

Source: author's elaboration based on Siedlecka A. (2015). Conditions and prospects for the development of organic farms in natural valuable areas of the lubelskie province, Polish Association of Agricultural and Agribusiness Economists Scientific Annals, Volume 17, Issue 6, pp. 240-245 


\section{Research results and discussion}

The ability to live in the vicinity of Natura 2000 protected areas is an everyday reality for many people, this is confirmed by Figure 1, where it is shown, how large these areas are in some countries.

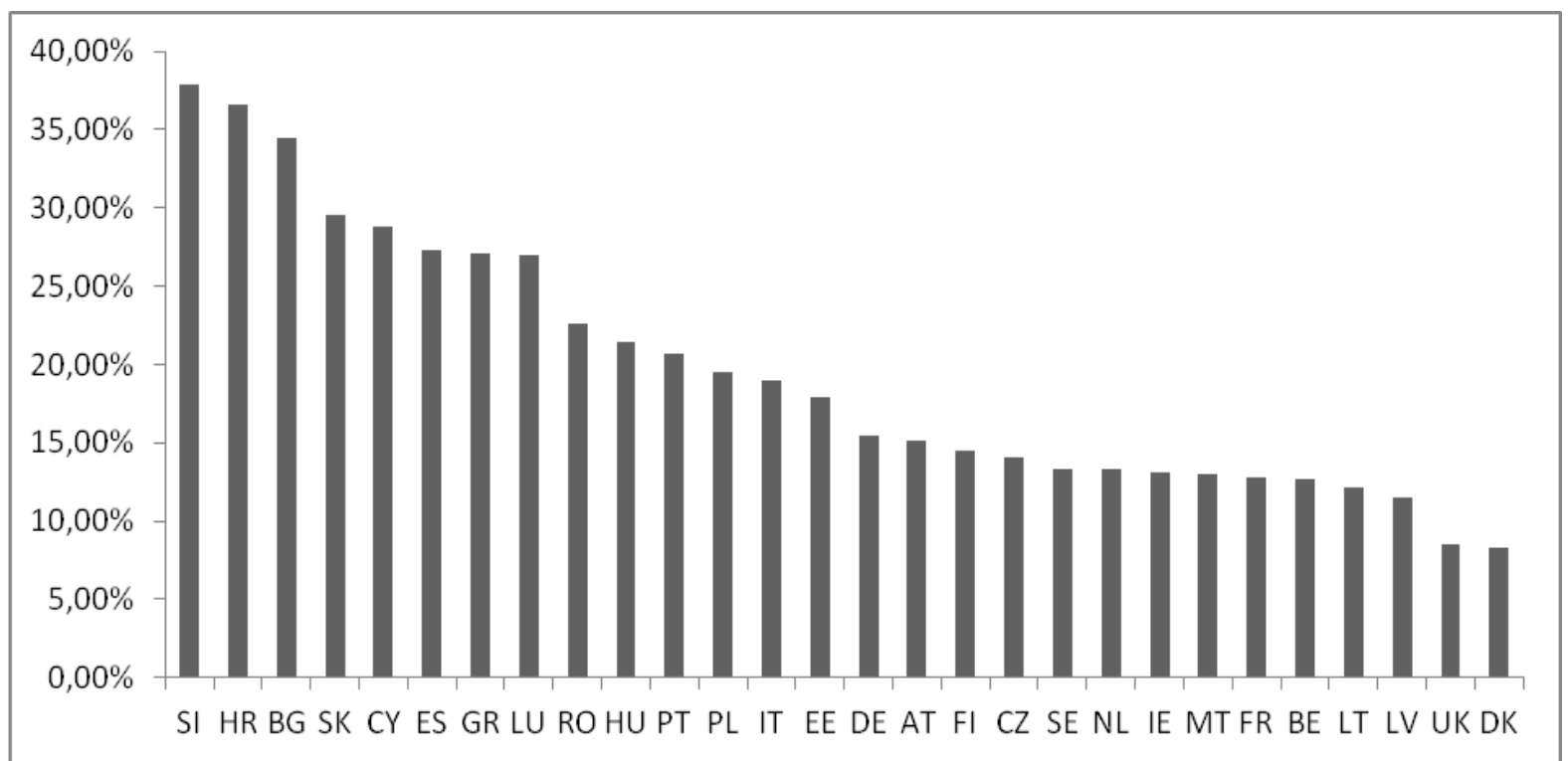

Source: author's elaboration based on

http://ec.europa.eu/environment/nature/natura2000/barometer/index_en.htm

Fig. 1. Proportion of land area in the European Union Member States covered by Natura 2000 (outcome as of 03.02.2016), \%

In the case of Slovenia, Croatia and Bulgaria, protected areas of Natura 2000 occupy over 1/3 of the countries. While in Slovakia, Cyprus, Spain, Greece and Luxembourg, these extents are almost one third of the countries' area. On the other hand, the United Kingdom and Denmark have less than $10 \%$ of the areas covered by the Natura 2000 Program. The remaining countries of the European Union have between 10 and $20 \%$ of their area covered by protected areas Natura 2000.

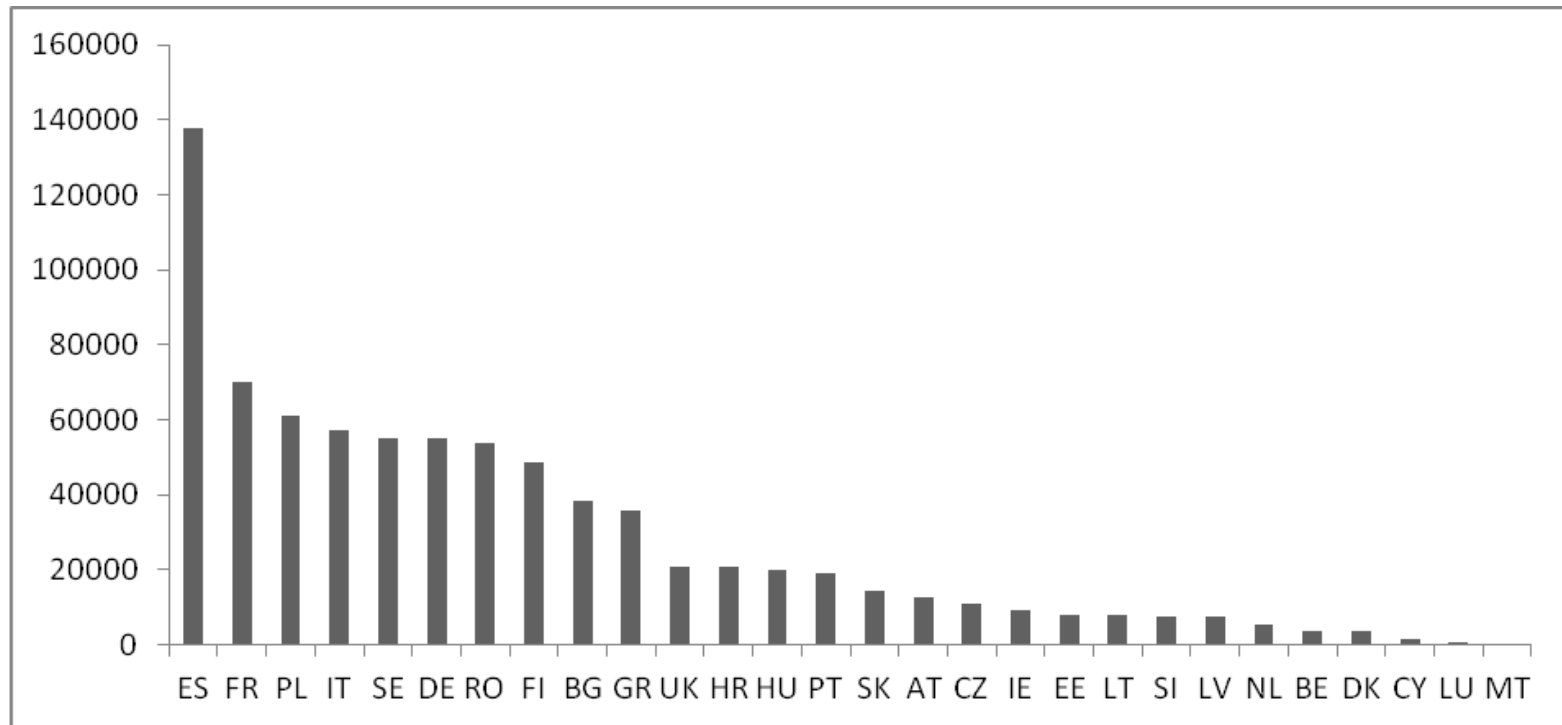

Source: author's elaboration based on

http://ec.europa.eu/environment/nature/natura2000/barometer/index_en.htm

Fig. 2. Natura 2000 area per EU Member State $\left(\mathrm{km}^{2}\right)$ (as of 03.02.2016)

Figure 2 shows Natura 2000 area per European Union Member State in square kilometres. It is seen as how very Spain stands out from the other countries. $137757 \mathrm{~km}^{2}$ of surface is Natura 2000 
protected areas. The second country with the largest surface area is almost half the size, it is France, whose protected areas are $69974 \mathrm{~km}^{2}$. It should be emphasized that Spain is not the largest country in the European Union, France occupies 46855 square kilometres more than Spain. The smallest area of protected fields is in Malta covering only 41 square kilometres.

Then analysed Site of Community Importance - SCI, which is defined in the European Commission Habitats Directive (92/43/EEC) as a site which, in the biogeographical region or regions to which it belongs, contributes significantly to the maintenance or restoration at a favourable conservation status of a natural habitat type or of a species and may also contribute significantly to the coherence of Natura 2000, and/or contributes significantly to the maintenance of biological diversity within the biogeographic region or regions concerned (European Environment Agency). SCI terrestrial areas are the biggest also in Spain (Figure 3). SCI areas in Spain are $117395 \mathrm{~km}^{2}$ followed by Sweden with more than half less $-54745 \mathrm{~km}^{2}$.

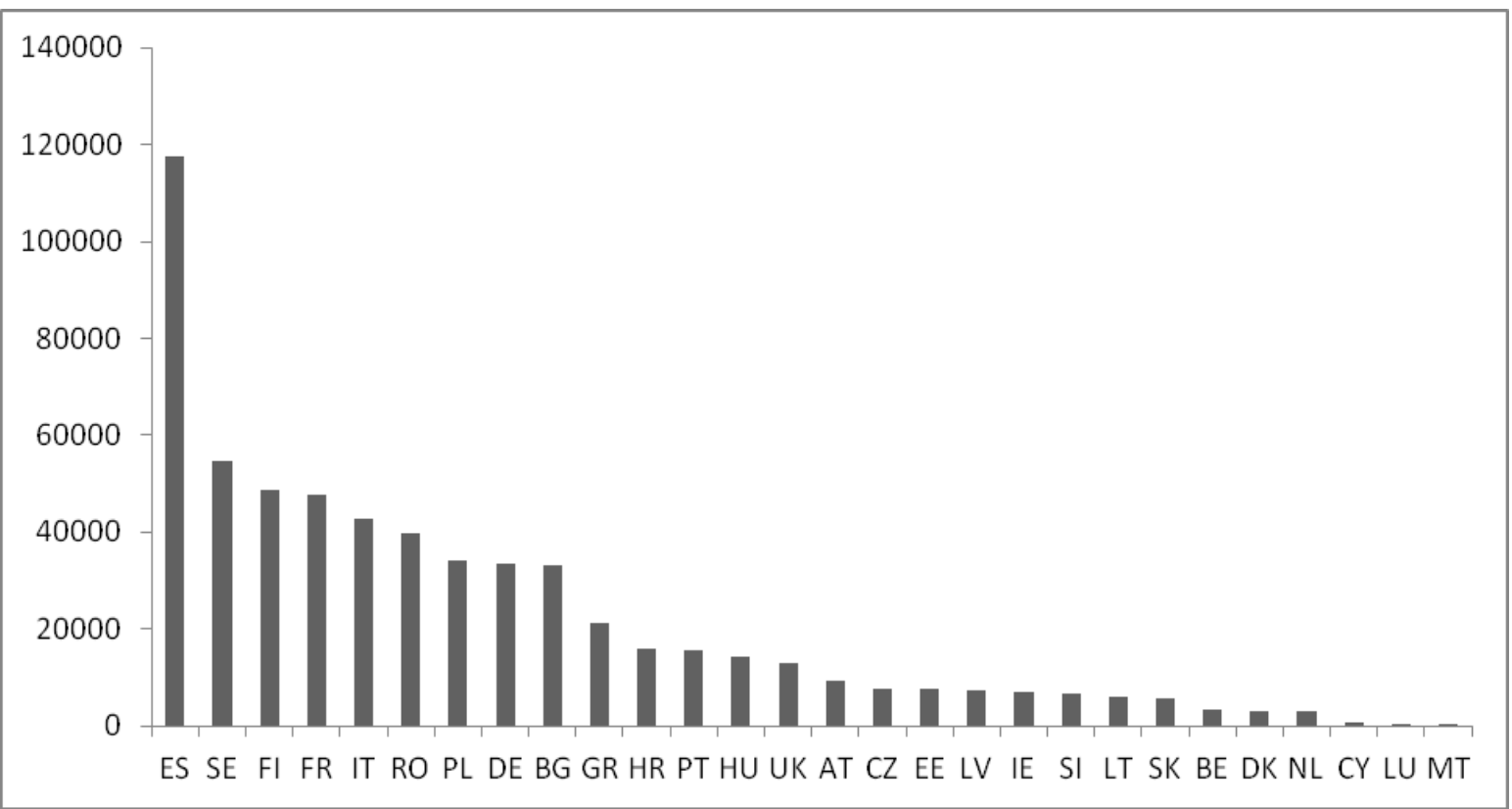

Source: author's elaboration based on

http://ec.europa.eu/environment/nature/natura2000/barometer/index_en.htm

Fig. 3. SCI terrestrial area data per EU Member State $\left(\mathrm{km}^{2}\right)$ (as of 03.02.2016)

Figure 4 presents Special Protection Areas - SPA. These are a designation under the European Union Directive on the Conservation of Wild Birds. Under the Directive, Member States of the European Union (EU) have a duty to safeguard the habitats of migratory birds and certain particularly threatened birds. Together with Special Areas of Conservation (SACs), the SPAs form a network of protected sites across the EU, called Natura 2000 (European Environment Agency).

Spain also excels here $-100972 \mathrm{~km}^{2}$ are special SPA fields. Less than fifty thousand square kilometres are occupied by Poland ranking it in the second position. For comparison, Malta has only $13 \mathrm{~km}^{2}$ of SPA terrestrial areas. 


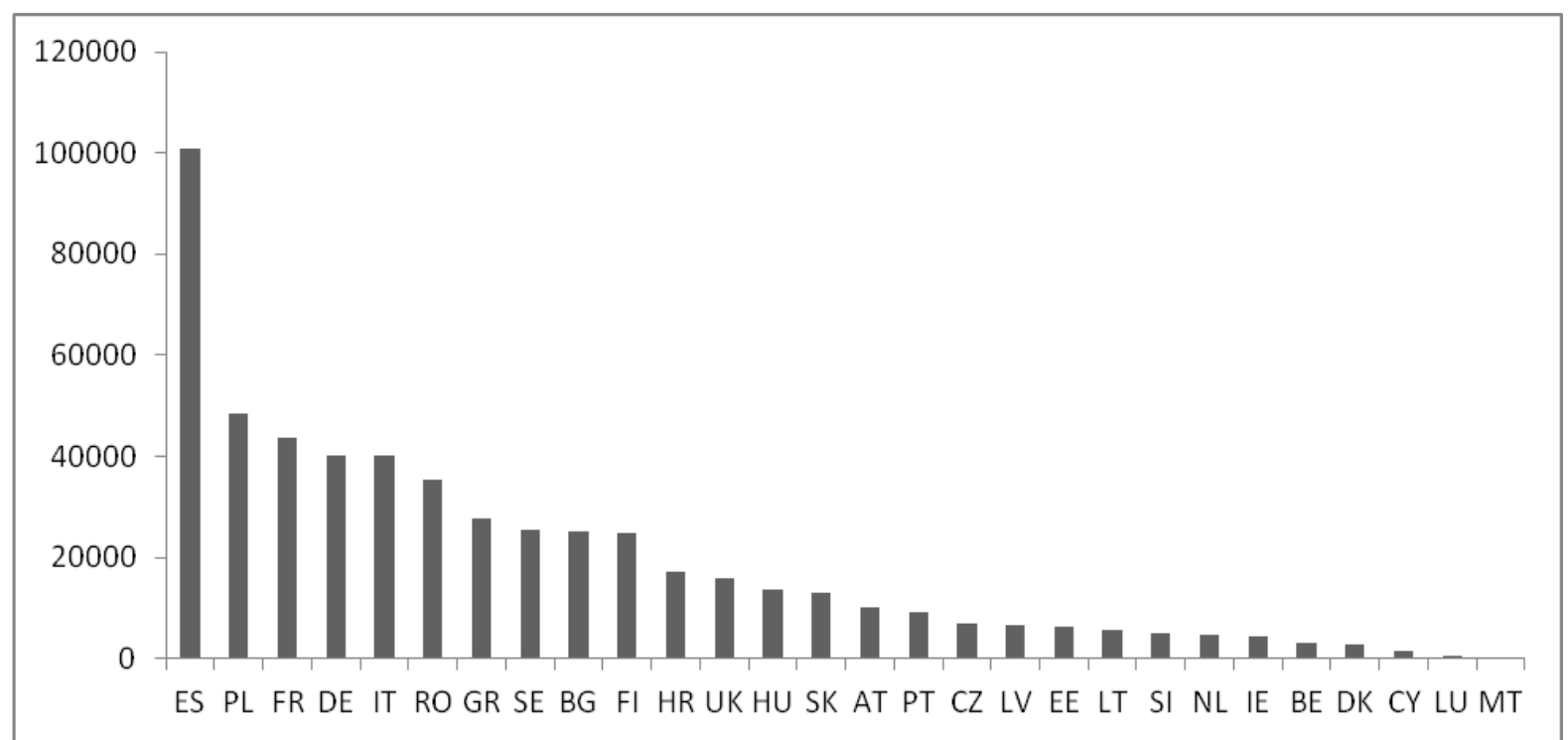

Source: author's elaboration based on

http://ec.europa.eu/environment/nature/natura2000/barometer/index_en.htm

Fig. 4. SPA terrestrial area data per EU Member State $\left(\mathbf{k m}^{2}\right)$ (as of 03.02.2016)

Then, environmental protection transfers by environmental protection activity and institutional sector were analysed. The countries of the European Union were selected for which data continuity was maintained in 2010-2014. Therefore, the Czech Republic, Denmark, Germany, Spain, France, Italy, Latvia, Lithuania, Luxembourg, Poland, Slovenia, Sweden, the United Kingdom were selected for the research.

Environmental protection transfers by environmental protection activity and institutional sector (million euro)

\begin{tabular}{|l|c|c|c|c|c|}
\hline \multicolumn{1}{|c|}{ Country } & $\mathbf{2 0 1 0}$ & $\mathbf{2 0 1 1}$ & $\mathbf{2 0 1 2}$ & $\mathbf{2 0 1 3}$ & $\mathbf{2 0 1 4}$ \\
\hline Czech Republic & 187.55 & 464.74 & 487.34 & 163.9 & 103.97 \\
\hline Denmark & 367.45 & 313.17 & 396.58 & 519.2 & 322.33 \\
\hline Germany & 2798 & 2198 & 2734 & 3106 & 3555 \\
\hline Spain & 530 & 448 & 343 & 392 & 480 \\
\hline France & 173.38 & 1231.42 & 1178.38 & 1351.55 & 1040 \\
\hline Italy & 743 & 662 & 629 & 718 & 644 \\
\hline Latvia & 8.19 & 13.33 & 28.31 & 25.58 & 24.28 \\
\hline Lithuania & 3.79 & 8.4 & 11.91 & 32.13 & 57.67 \\
\hline Luxembourg & 72.32 & 58.49 & 74.91 & 51.79 & 103.01 \\
\hline Poland & 232.69 & 284.91 & 383.53 & 327.31 & 317.01 \\
\hline Slovenia & 49.1 & 64.3 & 52.1 & 52.1 & 31.3 \\
\hline Sweden & 255.1 & 289.6 & 312.15 & 307.69 & 265.98 \\
\hline $\begin{array}{l}\text { United } \\
\text { Kingdom }\end{array}$ & 1556.23 & 1189.1 & 949.6 & 724.16 & 1424.11 \\
\hline / & & & & & \\
\hline
\end{tabular}

Source: http://ec.europa.eu/eurostat/data/database

Table 2 presents environmental protection transfers by environmental protection activity and institutional sector. In the analysed period 2010-2012, there was a visible increase in the environmental protection transfers by environmental protection activity and institutional sector in the countries of the so-called New Union, which later joined the EU. In the same period, a decline was recorded in other analysed countries. These data indicated a large irregularity among countries. 
In the Table 3, the chain indicates and the average pace of change in each country is specified. When analysing the values of the chain indices and average pace of change of the environmental protection transfers by environmental protection activity and institutional sector, it may be established that there was a very high irregularity in quotas. For example, for the Czech Republic, Denmark, Spain, France, Italy, Slovenia, the United Kingdom the average paces of change were negative, while in Germany, Latvia, Lithuania, Luxembourg and Poland they were positive.

Chain indices and average pace of change of environmental protection transfers by environmental protection activity and institutional sector

\begin{tabular}{|l|c|c|c|c|c|}
\hline \multicolumn{1}{|c|}{ Country } & $\mathbf{2 0 1 1}$ & $\mathbf{2 0 1 2}$ & $\mathbf{2 0 1 3}$ & $\mathbf{2 0 1 4}$ & $\begin{array}{c}\text { Average } \\
\text { pace of } \\
\text { change }\end{array}$ \\
\hline Czech Republic & 2.48 & 1.05 & 0.34 & 0.63 & $\mathbf{0 . 8 6}$ \\
\hline Denmark & 0.85 & 1.27 & 1.31 & 0.62 & $\mathbf{0 . 9 7}$ \\
\hline Germany & 0.79 & 1.24 & 1.14 & 1.14 & $\mathbf{1 . 0 6}$ \\
\hline Spain & 0.85 & 0.77 & 1.14 & 1.22 & $\mathbf{0 . 9 8}$ \\
\hline France & 0.71 & 0.96 & 1.15 & 0.77 & $\mathbf{0 . 8 8}$ \\
\hline Italy & 0.89 & 0.95 & 1.14 & 0.90 & $\mathbf{0 . 9 6}$ \\
\hline Latvia & 1.63 & 2.12 & 0.90 & 0.95 & $\mathbf{1 . 3 1}$ \\
\hline Lithuania & 2.2 & 1.4 & 2.7 & 1.8 & $\mathbf{2 . 0}$ \\
\hline Luxembourg & 0.81 & 1.28 & 0.69 & 1.99 & $\mathbf{1 . 0 9}$ \\
\hline Poland & 1.22 & 1.35 & 0.85 & 0.97 & $\mathbf{1 . 0 8}$ \\
\hline Slovenia & 1.3 & 0.8 & 1.0 & 0.6 & $\mathbf{0 . 9}$ \\
\hline Sweden & 1.1 & 1.1 & 1.0 & 0.9 & $\mathbf{1 . 0}$ \\
\hline $\begin{array}{l}\text { United } \\
\text { Kingdom }\end{array}$ & 0.76 & 0.80 & 0.76 & 1.97 & $\mathbf{0 . 9 8}$ \\
\hline
\end{tabular}

Source: author's calculations based on http://ec.europa.eu/eurostat/data/database

\section{Conclusions, proposals, recommendations}

1) Natura 2000 is an area protection programme that not only cares about the environment, but also includes various possibilities for society. It is, for example, an impulse to start running ecological farming.

2) In Slovenia, Croatia and Bulgaria, protected areas of Natura 2000 occupy over $1 / 3$ of these countries' areas.

3) Spain stands out from the other countries in case of Natura 2000 area in $\mathrm{km}^{2}$. The second country - France is almost half the size.

4) In Spain, SCI terrestrial areas are also the biggest - $117395 \mathrm{~km}^{2}$ followed by Sweden on the second position with more than half less $-54745 \mathrm{~km}^{2}$. Spain also excels in SPA $-100972 \mathrm{~km}^{2}$ are special SPA fields. Less than fifty thousand square kilometres are occupied by Poland ranking it in the second position.

5) In the analysed period 2010-2012, there was a visible increase in the environmental protection transfers by environmental protection activity and institutional sector in the countries of the socalled New Union, which later joined the EU. In the same period, a decline was recorded in other analysed countries.

6) Resolved environmental protection transfers by environmental protection activity and institutional sector indicated a large irregularity among chosen countries. 


\section{Bibliography}

1. Bera, M. (2014). Rolnictwo ekologiczne jako czynnik rozwojowy gmin polozonych na obszarach chronionych (Organic Farming as a Development Factor for Municipalities located in Protected Areas), Progress in Economic Sciences, No. 1, pp. 121-129.

2. Brodzinska, K. (2013). Kierunki i mozliwosci rozwoju gospodarstw rolnych na obszarach Natura 2000 (Directions and Possibilities of Farm's Development in Natura 2000 Area), Polish Association of Agricultural and Agribusiness Economists Scientific Annals, Volume 15, Issue 6, pp. 33-38.

3. Generalna Dyrekcja Ochrony Srodowiska (2014). Natura 2000 w Europe (Natura 2000 in Europe), http://natura2000.gdos.gov.pl/natura-2000-w-europie Access: 04.02.2018.

4. Golebiewska, B. (2009). Production Resources and their Use in Farms of Varied Relations with the Environment in Poland, Economic Science for Rural Development No. 20, pp. 27-32.

5. Golebiewska, B. (2015). The Relationships of Ecological and Economic Use of Natural Resources, Proceedings of the 2015 International Conference "ECONOMIC SCIENCE FOR RURAL DEVELOPMENT" No37 Jelgava, LLU ESAF, 23-24 April 2015, pp. 114-121

6. Golebiewska, B., Pajewski, T. (2015). Odpowiedzialnosc rolnikow za stan srodowiska naturalnego (The Liability of Farmers for The Natural Environment), Polish Association of Agricultural And Agribusiness Economists Scientific Annals, Volume 17, Issue 2, pp. 64-68.

7. https://www.eea.europa.eu/help/glossary\#c4=10\&c0=all\&b_start=0 Access: 03.02.2018

8. Jack, B. (2009). Agriculture and EU Environmental Law. Routledge, Belfast, p. 142

9. Kamieniecka, J., Wojcik B. (2010). Natura 2000 ABC dla turystyki (Natura 2000 ABC for Tourism), Instytut na rzecz Ekorozwoju, Warsaw, p. 17.

10. Kielsznia, M. (2010). Funkcjonowanie gospodarstw rolnych na obszarach chronionych w Polsce na przykladzie Kampinoskiego Parku Narodowego (Functioning of Farms in Protected Areas in Poland on the Example of the Kampinos National Park), Folia Pomer. Univ. Technol. Stetin Oeconomica, Volume 277, Issue 58, pp. 21-26.

11. Mickiewicz, B., Gotkiewicz, W. (2010). Znaczenie i rola obszarow Natura 2000 w zyciu gospodarczym gminy (Meaning and Role of Natura 2000 Areas in Economic Life of Commune), Ochrona Srodowiska i Zasobow Naturalnych, No. 45, pp. 145-152.

12. Natura 2000 Barometer (2016). http://ec.europa.eu/environment/nature/natura2000/barometer/index_en.htm Access: 04.02.2018.

13. Perepeczko, B. (2012). Drobne gospodarstwa rolne na wiejskich obszarach Natura 2000 (Small Farms in the Natura 2000 Rural Areas), Problems of Small Agricultural Holdings 1/2012, pp. 115-128.

14. Siedlecka A. (2015). Conditions and Prospects for the Development of Organic Farms in Natural Valuable Areas of the Lubelskie Province, Polish Association of Agricultural And Agribusiness Economists Scientific Annals, Volume 17, Issue 6, pp. 240-245.

15. Szramka, M., Zebek, E. (2013). Ograniczenia realizacji przedsiewziec na obszarach Natura 2000 (Limitations on The Implementation of Projects in Natura 2000 Areas), Studia Prawnoustrojowe, No. 22, pp. 195-206.

16. Wielewska, I. (2017). Eco-innovations and Sustainable Development of Businesses in Rural Areas of Kujawsko-pomorskie Province of Poland, Proceedings of the 2017 International Conference "ECONOMIC SCIENCE FOR RURAL DEVELOPMENT" No. 44, Jelgava, LLU ESAF, 27-28 April 2017, pp. 205-211.

17. Wos A., Zegar J. (2002). Rolnictwo spolecznie zrownowazone (Socially Sustainable Agriculture). Wyd. IERiGZ, Warszawa. p. 111.

18. Zapolska, K. (2012). https://www.law.muni.cz/sborniky/dny_prava_2012/files/Verejnafinancnicinnost/ ZapolskaKarolina.pdf Access: 06.02.2018 